\title{
Technè
}

La science au service de l'histoire de l'art et de la préservation des biens culturels

$44 \mid 2016$

Archives de l'humanité : les restes humains patrimonialisés

\section{The Conservation of Egyptian mummies in Italy}

La restauration des momies égyptiennes en Italie

\section{Cinzia Oliva}

\section{(2) OpenEdition}

1 Journals

\section{Electronic version}

URL: http://journals.openedition.org/techne/1205

DOI: 10.4000/techne.1205

ISSN: 2534-5168

\section{Publisher}

C2RMF

\section{Printed version}

Date of publication: 1 November 2016

Number of pages: $122-126$

ISBN: 978-2-7118-6339-6

ISSN: 1254-7867

\section{Electronic reference}

Cinzia Oliva, «The Conservation of Egyptian mummies in Italy », Technè [Online], 44 | 2016, Online since 19 December 2019, connection on 23 July 2020. URL : http://journals.openedition.org/techne/ 1205 ; DOI : https://doi.org/10.4000/techne.1205

\section{(ब) $\Theta \Theta$}

La revue Technè. La science au service de l'histoire de l'art et de la préservation des biens culturels est mise à disposition selon les termes de la Licence Creative Commons Attribution - Pas d'Utilisation Commerciale - Pas de Modification 4.0 International. 
Cinzia Oliva

\section{The Conservation of Egyptian mummies in Italy}

La restauration des momies égyptiennes en Italie

Abstract. The conservation of mummies and human remains in Italian collections is a relatively new field. The earliest scientific studies of mummies date back to the 1960's, but the first systematic use of CT (Computed Tomography) - scan on human mummies had to wait until the $21^{\text {st }}$ century. The main interest of these studies was what was inside a mummy, with less attention paid to the textiles and related materials. Conservation of mummies has faced a series of problems: historical pillaging, past treatments, museum or storage environments, natural decay of organic material, and exhibition requirements. This paper illustrates the main cleaning and supporting techniques used in Italy by two case studies, both of which have parts of the bodies exposed. One is from the Egyptian Museum in Turin (Inv. Cat. 2218) and the second is kept in storage in the Vatican Museums (Inv. 25004). I faced the same problems with both, but resolved them in different ways.

Keywords. Mummy, conservation, human remains, Italy, textiles, Egypt, Vatican Mummy Project, nylon (or polyamide) net.
Résumé. La restauration des momies et des restes humains dans les collections italiennes est un domaine relativement nouveau. Les plus anciennes analyses scientifiques de momies remontent aux années 1960, mais l'utilisation systématique de la tomodensitométrie sur des restes humains ne date que du XXI $I^{e}$ siècle, permettant de se concentrer sur l'intérieur du corps de la momie sans s'arrêter aux textiles extérieurs. La restauration des momies se heurte à de nombreuses difficultés : pillage des tombes, traitements antérieurs, conditions climatiques dans le musée et les réserves, dégradation naturelle des tissus biologiques et contraintes d'exposition. Deux exemples illustrent ici les principales techniques de nettoyage, consolidation et refixage employées en Italie. Il s'agit de deux momies dont certaines parties du corps sont à nu, conservées respectivement au Museo Egizio de Turin (inv. 2218) et dans les collections égyptiennes des musées du Vatican (inv. 25004). Deux solutions différentes ont été apportées à un problème identique.

Mots-clés. Momie, restauration, restes humains, Italie, textiles, Égypte, Vatican Mummy Project, filet en polyamide.
During the 19th century, Egyptian mummies were "first" items of curiosity and were sought after by collectors. Most of the mummies arrived in museums after complex and troubled wanderings: sometimes they were acquired officially or most often through the antiquities market, and they often entered public and private collections some time after their original discovery. This situation explains why their provenance is often unknown and the history of conservation is sometimes unclear and difficult to establish.

Early investigations and studies on Egyptian mummies focussed on the body and the objects laid upon it, with little attention and care expended on the textile wrappings, or the "object" as a whole. Until the early $20^{\text {th }}$ century, when X-rays started to be used, generally mummies were studied by being unwrapped, with the textiles often being destroyed in the process ${ }^{1}$; indeed, such autopsies continued to be carried out until the early $1970 \mathrm{~s}^{2}$. In Italy, the first systematic X-ray investigations was carried out by Renato Grilletto and Enzo De Lorenzi on mummies from the Museo Egizio in Turin. It started in the 1960s and lasted until the $1980 \mathrm{~s}^{3}$. In 2001, a campaign of CT-scan was carried out on 24 mummies from the Museo Egizio and from the Museum of Anthropology in Turin by the Institute of Diagnostic and Interventional Radiology of the University of Turin ${ }^{4}$. In 2007 the Oriental Antiquities Department of the Vatican Museums, under the direction of Alessia Amenta, established a project for the study and conservation of the human and animal mummies, in collaboration with the Laboratory of Diagnostic for Conservation of the Vatican Museums, directed by Ulderico Santamaria ${ }^{5}$.

\section{Conservation of mummies}

Mummies, being an ever-popular attraction for the public, have been on long-term display in museums, but the attention was given solely to the scientific aspects of the bodies and not to the conservation and care of the associated materials, like textile wrappings, dyed shrouds, painted cartonnage, leafs and flowers wreaths which decorated and completed the 
mummies. As a consequence of being on display, most of the mummies belonging to museum collections have undergone some sort of treatment over the years, most of which relates to a temporary consolidation of broken fibres and wrappings. The attention given to archaeological textiles coming from excavation sites or public collections, is quite recent in Italy and there is a lack of literature on the subject, especially when compared to other materials such as painted wood, stone or metalwork. Thus, in the past, conservators from unrelated fields (painting, paper and parchment) were entrusted with the treatment of mummies. Their lack of experience with textiles and the use of methodologies, which were sometimes too aggressive, and the application of unsuitable materials for cleaning and supporting, accelerated the degradation of fibres and artefacts, producing a general brittleness and irreversible alteration of colour and condition of the original material. Sometimes, these treatments resulted in a loss of technical information about the mummies' construction and their history.

In the Museo Egizio of Turin, I found several textiles and mummies that had been conserved by a paper conservator, who had worked on the papyrus collection during the 1930s. She consolidated tears and lacks using starch and paper and/ or silk crepeline as a support. This was in keeping with the standards of that period. Over time, and with the prolonged exposure to light and pollutants, both the glue and the support degraded. This produced a change in colour and rendered the artefacts stiff and brittle, resulting in a considerable loss of their mechanical strength. The textiles were stained, more fragile and, in some cases, their original shape and dimensions were irreversibly altered.

The idea of 'minimum intervention' ${ }^{6}$ is now widely accepted as the best approach to take when working on archaeological materials in order to preserve both the artefact and all the technical information relating to its original function, production, technologies and provenance. Furthermore, conservation has a key role in making human remains available and accessible for long-term study ${ }^{7}$. For this reason, it is essential to avoid, as much as possible, using materials and techniques which, in the long term, could alter the artefact and compromise future analyses.

The aim of any treatment should be to extend the 'life' of an artefact in order to keep all the intrinsic information available, for example the history of the object, collection or human remains. Any treatments which involve human remains and their accessories (wrappings, cartonnage, shrouds, bead nets, etc.) create a sort of filter which can conceal, reveal or highlight different aspects of the objects, and the conservator is always responsible and emotionally involved in this decision. I would like to bring attention to the emotional and, potentially distressing emotions that can be present when carrying out conservation work in the presence of the $\mathrm{dead}^{8}$.

In an ideal world, a non-interventionist approach would be best for these kind of artefacts, knowing that even the minimal treatment can cause undesirable changes and a potential loss of information. But mummies and objects which have suffered the natural decay of organic materials and prolonged display in museums in industrial and polluted towns - where the majority of collections are located - often force conservators to find new ways of addressing all these potential challenges. Different problems have to be faced which require varied solutions, which, unfortunately, do not always involve minimum intervention.

Cleaning is always an irreversible process that can result in loss of information, but at the same time, it can be useful in preserving the artefact by removing dangerous deposits from the fibres and helping to understand the nature of the fragment or the structure of the object. Careful attention has to be paid to ensure that no original soil or deposits, resulting from mummification or funerary rituals are removed. However, textiles that have been on display often exhibit signs of damage due to atmospheric pollution, mechanical stress and excessive light.

Thick dust deposits can often cover the entire surface of textiles and the fibres of objects, that are folded for prolonged periods, can demonstrate physical damage and mechanical stress. In such cases, wet cleaning treatment might be necessary to improve the $\mathrm{pH}$ of fibres (making them more neutral) and to lessen any undesirable deformation that could result in further damage in the future.

In the conservation of a mummy belonging to the Museo Egizio in Turin (Inv. Suppl. 5227-XXV Dynasty), the outer shroud that was dyed red was covered with thick dust deposits that had altered its original colour to a greysh brown and had weakened the structure, already damaged by historical looting. The shroud had already been removed from its original position on the body, as was ascertained from previous documentation, and showed several gaps and cuts on its surface. Thus, we decided to remove the textile from the mummy and proceeded with a surface cleaning with a micro-vacuum and local wet cleaning (on acid-free blotting paper), to remove the deposits of dust and to relax the fibres after their long-term display. Careful attention was paid to the initial moistening process and to the drying techniques, in order to replace fibres in the right position and recover the original orthogonality of the fabric ${ }^{9}$.

Following the cleaning of a mummy, the subsequent challenge posed to the conservator is providing fragile and degraded wrappings and human remains with adequate support. The choice of methods are determined not only by the weakness of the artefact, but also by its three-dimensional shape and future "museum life". In mummy conservation, the main problem to solve is surface consolidation, keeping the fragments in place without producing any chemical and visual alteration in the fibres. Most of the time, there is no access from the back of the textiles, so it has to be consolidated from the front or displayed side. Thus, any new material that is used to support the old has to be as transparent as possible, easy to manipulate and to dye (in order to match the original colour of the wrappings), with possibly non fraying-edges and enough elasticity to follow the mummy's shape. 
For this reason, when I started to work on Egyptian mummies in $2000^{10}$, I decided to choose a fine reticulated nylon net fabric. This support can partially, or totally, encapsulate the body, depending on the state of conservation of the mummy, and can be kept in place with a minimum of stitching (through a properly dyed silk or linen ribbon), or simply with strips of Velcro sewn on one side of the support fabric. The treatment is minimal, non-invasive, and the net can be easily removed; the mummy is clearly visible below it, while the conservation netting remains largely invisible to the museum visitor, unless closely scrutinised ${ }^{11}$.

\section{Case Study 1: Mummy of Tamit (Museo Egizio of Turin, Inv. Cat. 2218)}

In 2014, I conserved the so-called "Three Sisters" group of mummies, dated to the Late Period (22th-25th Dynasty) and displayed in the Museo Egizio ${ }^{12}$. The mummies of Tamit, Tapeni and Renpetnefret were acquired with the Drovetti collection in $1824^{13}$. Their provenance is not recorded but according to textual and stylistic criteria they were probably discovered in the Theban necropolis. The mummies are preserved inside their coffins which, based on iconographic studies ${ }^{14}$ date from the $25^{\text {th }}$ dynasty. They are called the 'Three Sisters' because, as is stated in the inscription, all three are the daughters of the Amun priest Ankhkhonsu and of the lady Neskhonsu.

Conservation followed the radiological and chemical analyses for the identification of fibres and dyestuffs. The skeletons were in a good condition, showing similar embalming techniques, even if each mummies presented differences in their external construction (two of them had an outer shrouds dyed red, one had traces of a bead-net).

All three mummies were in a state of advanced degradation, caused in part from natural decay of the organic materials, and in part due to being on display for a long time, but the most significant damage was due to ancient looting, when Tamit had been partly destroyed by looters in their search for amulets and jewellery.

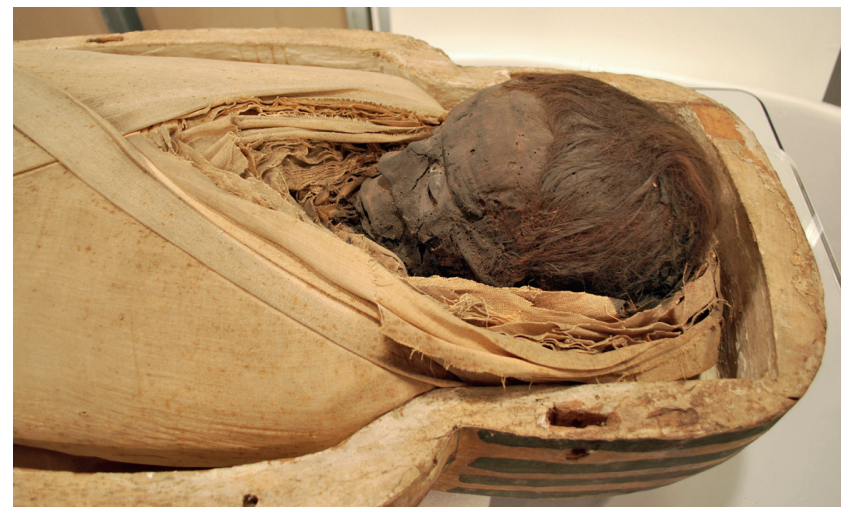

Fig. 1. Case study 1. Mummy of Tamit (Inv. Cat. 2215). Detail of the head before conservation. (C) Museo Egizio Torino/C. Oliva.
The wrappings of the head of the mummy named Tamit (Inv. Cat. 2218) showed deep circular cuts, which left the front of the skull completely uncovered, resulting in a considerable loss of material from this area. Parts of the bandages had been ripped off and left detached and distorted around the head, making the flesh and bone more brittle (fig. 1).

\section{Treatment}

The mummy of Tamit was moved onto a transparent board of Plexiglass in order to have full access to the back of the body and to proceed with the usual graphic and digital documentation. Textiles and shrouds identified on the mummy were studied, and for each of them a record sheet was created, containing the following information: fibre, torsion, weaving reduction, selvedge, starting and finishing borders, fringe. Tamit had been wrapped in one external unbleached shroud, folded back over the head and feet, leaving the centre of the back uncovered, and knotted, with the final part of the straps under the neck. The shroud is finished on the long sides by a selvedge and a rolled and whipped hem, and kept in place by a number of strips of a slightly coarser linen. Further details could be seen through the (regrettable) violation of the mummy in antiquity. It seemed as if she had been wrapped in at least seven different textiles, of which two probably belong to wider shrouds. They showed decorative bands, one alternating with blue and the other with red wefts, with long and twisted fringes.

The poor condition of the mummy and the effect of the looting required serious treatment to remove the dusty deposits from the exposed sections of wrappings and human remains, which were heavily darkened and dehydrated.

The work began with a vacuum cleaning of the entire surface, with the help of soft brush, and the gentle action of vulcanised sponges to remove the dirt from the surface. The soft tissue of the face, too brittle and fragile to stand any kind of mechanical action, was cleaned locally with a small cotton swab and the help of an ultrasonic humidifier, with cold steam, in order to soften the greasy film as much as possible.

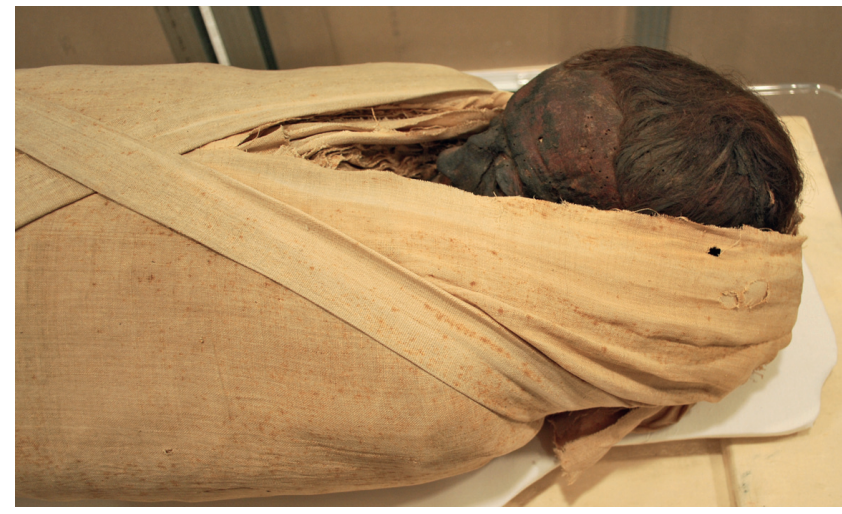

Fig. 2. Case Study 1. Mummy of Tamit (Inv. Cat. 2215). Detail of the head after conservation, with the inserted cushion and supported by net. (C) Museo Egizio Torino/C. Oliva. 


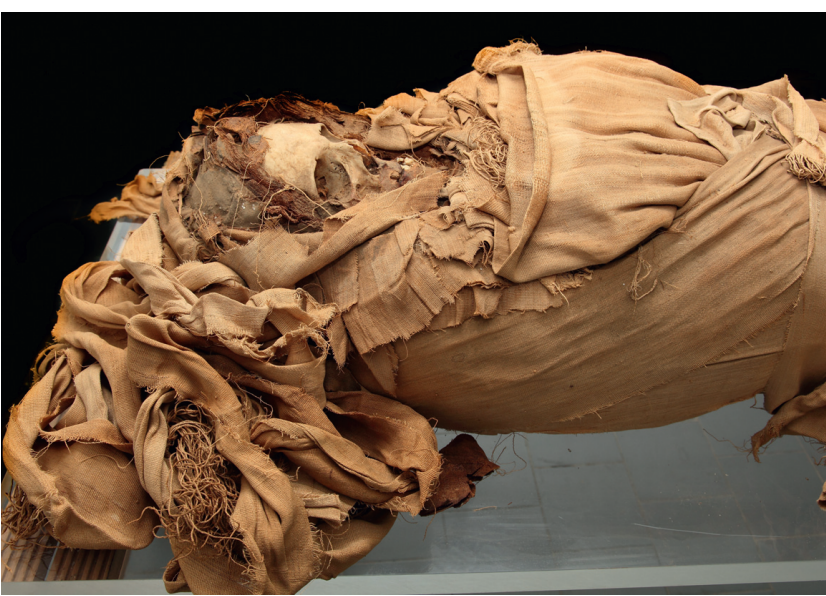

Fig. 3. Case study 2. Mummy (Inv. 25004). Detail of the head before conservation with the skull uncovered and ripped off bandages. (C) Musei Vaticani.

The major challenge was to re-construct the original shape of Tamit's head wrappings to what it had been prior to looting, as that act had resulted in the cutting off and removal of the bandages in the head area and in a visible loss of mechanical tension in the textiles (fig. 1). The bandages, still in situ, were first re-shaped with cold steam and then breaks and cuts in them were stitched locally on nylon net; the gap was then filled with a specially shaped-padded cushion, inserted on the right hand side of the skull. The cushion was made from polyester wadding covered with dyed linen stitched onto itself, so as to avoid the use of any glues that could contaminate the original fabrics.

All the fragments were positioned and kept in place, over this support, by a nylon net, draped around the head, and sewn onto itself rather than onto the object, with very few stitches through the strongest external original bandages, to keep it in place (fig. 2).

In this way, all the original fragments were kept in place, while achieving the goal of covering and protecting part of the human remains and preserving evidence of historic pillaging.

\section{Case study 2: Mummy (Vatican Museums, Inv. 25004)}

Male (?) mummy, dated to the 21th or early 22th Dynasty (radiocarbon dating), is conserved in the storage in the Vatican Museum. In 2013, before the beginning of the conservation, the mummy underwent a detailed morphological inspection and analyses following the protocol of the Vatican Mummy Project ${ }^{15}$.

The treatment of this mummy followed a process quite similar to that described in Case study 1. The mummy was moved to a Plexiglas board and fully documented. During the study of textiles and thanks to the evident and extensive damage caused by the looting, 12 fragments of detached bandages and 4 shrouds positioned and folded over the chest,

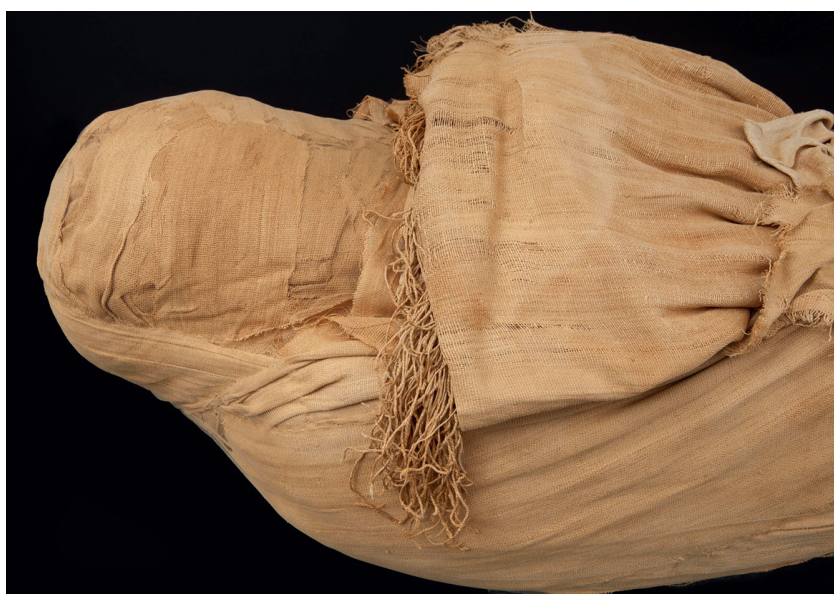

Fig. 4. Case study 2. Mummy (Inv. 25004). Detail of the head after conservation. (C) Musei Vaticani.

in order to re-create the former shape of the body, were found From this material and through a comparison between the visual, technical and chemical test of the fibres, it was possible to identify three different types of fabric.

\section{Treatment}

The mummy was in poor condition, partly due to the natural ageing of the linen fibres, and partly due to the vandalism that it had been victim to in the past. The remains were dusty, with thick deposits on the exposed sections, which had penetrated the fibres, thus accelerating the mechanical decay of the cellulose, and producing breaks, cuts and a general weakness in the mechanical weaving structure. But the most significant damage was due to the looting itself.

Deep circular cuts on the head and feet and a T-shaped cut on the chest left both the skull and part of the feet completely uncovered, resulting in a considerable loss of material from these areas. Parts of the bandages had been ripped off, and were left detached along the body or roughly wrapped around it (fig. 3). The skull showed through the twisted and warped bandages, with a consequent general decay of the organic remains, as was the case with the feet.

The work started with the vacuum cleaning of the entire surface (the nozzle of the vacuum cleaner was protected with nylon net in order to protect the material), and humidification to flatten out the broken bandages in order to recover the original structure and orthogonality of the fabric and reconstruct, where possible, the original length of the detached bandages. The main problem to solve, as always, was how to consolidate the degraded sections and keep the fragments in place without producing any visual or chemical alteration to the fibres.

After the humidification, it was possible to reconstruct the original position of the wrappings. Most of the bandages were still in place and could easily cover the face, therefore it was decided to fill the gap over the skull left by the looters, 
with shaped padded cushion (see Case study 1) over which the fragmented bandages were replaced and kept in place by a local support of fine nylon net, sewn onto itself (fig. 4).

The feet were treated in the same way. As only a thin layer of bandages was missing, it was decided not to fill the gap and to leave the organic remains partially uncovered. The fragments were put in place and covered with the dyed nylon net, secured by stitching it onto itself. The net was then disguised under the original bandage, which turned around the ankles.

So as to avoid unnecessary stitching and excessive covering and in order to allow easy access to the material, the centre of the chest was protected with a local support: the nylon net was fixed, and kept in place, by narrow strips of Velcro, sewn onto just one side of the net and hidden along the lower part of the hip. This is completely reversible and removable, so as to permit the further study of these materials, especially the four shrouds.

\section{Conclusion}

The aim of the restoration work was to preserve both the original wrappings and the organic material and, at the same time, let the mummies to be displayed again properly.

The accidental and partial unwrapping of both the mummies and the conservation treatments allowed a deeper insight into the materials and the wrapping techniques used for mummies of this period. Further research and analysis on fibres and dyestuff and comparison with other mummies could lead to systematic studies on wrappings and textile used in funerary context.

The covering with net achieved the target: all the fragments are safely in place, the net produced a minimal visual changing of surface colour and the treatment is totally reversible and leaves open any other choice for the future.

Actually, Tamit is displayed in a wide showcase with the other two sisters at the first floor of the renewed Museo Egizio in Turin while the mummy of Vatican Museum is conserved in the climatized storage of the museum.
Notes

1. Ikram and Dodson, 1998

2. Taconis, 2005, p. 35-51.

3. De Lorenzi, Grilletto, 1989

4. Fiore Marocchetti , 2012.

5. The team includes: Biology Department, Universiy of Pisa; Entomological Laboratory, University of Pisa; Department of Bio-Imaging and Radiology, University of Messina; Institute for Mummies and Iceman, EURAC, Bolzano; Stephanie Panzer, Unfallklinik Murnau, radiologist; Sveva Longo, Science and Technology for Conservation for Cultural Heritage; Dario Piombino Mascali, Cultural Heritage Department of Palermo, palaeopathologist and bioarchaeologist; Cinzia Oliva, textile conservator; Cristina de' Medici, cartonnage conservator.

6. Brooks et $A l ., 1996$, p. 16-21.

7. Wills et $A l$., 2014, p.49-51.

8. Balachandran, 2009.

9. Conservation report (unpublished).

10. Oliva et $A l ., 2006$, p. 243-247.

11. Wills, 2014.

12. Borla, Oliva (forthcoming).

13. Fabretti et $A l l, 1882$, p. 297-298.

14. Connor, Facchetti, 2015, p 188.189.

15. Oliva (forthcoming).

\section{Bibliography}

Balachandran S., 2009, "Among the dead and their possessions: a conservator's role in the death, life and afterlife of human remains and their associated objects", Journal of the American Institute for Conservation, 48, n. 3, p. 199-222.

Borla M., Oliva C., forthcoming, The Mummies of the "Three Sisters" in the Museo Egizio: a case study. Conservation and studies of bandages and textiles, International Congress of Egyptology XI (Florence - 23th30th August 2015).

Brooks M., Lister A., Eastop D., Bennett T., 1996, "Artifacts or information? Articulating the conflicts in conserving archeological textiles", "Archaeological Conservation And Its Consequences"Preprints of the Contribution to the Copenaghen Congress, IIC, London, p.16-21.

Connor S., Facchetti F., "Epoca Tarda: religione, arte e usi funerari", in Museo Egizio, 2015, Modena, Panini, p. 188189.

De Lorenzi E, Grilletto R., 1989, Le mummie del Museo Egizio di Torino, N.1300113026: Indagine antroporadiologica, La Goliardica, Milano.

Fabretti A., Rossi A., Lanzone R. V., 1882, Regio Museo di Torino. Antichità Egizie. Vol. I, Torino.

Fiore Marocchetti E., 2012, "Mummie egizie in Piemonte", in Boano R. - Rabino Massa E. (dir.), Mummie Egizie in Piemonte, Museo Regionale di Scienze Naturali, Torino.

Ikram, S., Dodson, A., 1998, The Mummy in Ancient Egypt: Equipping the Dead for Eternity, Thames \& Hudson, London.
Oliva C., forthcoming, The Looting of a Mummy: an opportunity to explore the wrappings, in Burial and Mortuary Practices in Late Period and GraecoRoman Egypt, International Conference, Budapest 17th-19th July 2014.

Oliva C., Fiore Marocchetti E., Doneux K., Curti A., Janot F., 2006, "The mummies of Kha and Merit: Embalming Ritual and Restauration Work", in Rabino Massa E.(ed.), Proceedings V World Congress on Mummy Studies, Journal of Biological Research, n. 1, 2005, Rubettino, Catanzaro.

Raven M. J., Taconis W. K., 2005, Egyptian Mummies Radiological Atlas of the Collections in the National Museum of Antiquities in Leiden, Brepols, Turnhout.

Wills B., Ward C., Sáiz Gómez V., 2014, "Conservation of Human remains from Archaeological Context", in Fletcher A. Antoine D., Hill J. D. (ed.), Regarding the Dead: Human Remains in the British Museum, The British Museum, London, p. 49-73.

Wills B., 2014, "Wrapping the Wrapped: The Development of Minimal Conservation of Ancient Human Wrapped Mummies from the Region of the Nile", in L. Douny and S. Harris (ed.). Wrapping and Unwrapping Material Culture, Archaeological and Anthropological Approaches, Routledge, London, p. 157170. 